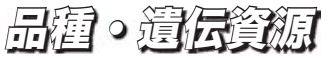

\section{四国山地西部に遺存するダイズ地方品種の生育・収量に 関係する諸形質および種子形態の変異}

\author{
原田光 ${ }^{1)} \cdot$ Nguyen Van Huan $^{2)}$ ・杉本秀樹 ${ }^{1)}$ \\ (1) 愛媛大学農学部, ${ }^{2}$ 愛媛大学大学院連合農学研究科)
}

\begin{abstract}
要旨：四国山地西部の山村農家から黄色種子 25 系統，黒色種子 17 系統，褐色種子 2 系統および緑色種子 10 系統から なる計 54 のダイズ地方品種系統を採集し, 固場で育成して生育・収量構成要因と種子形態の変異を調べた。枝分かれ 分散分析の結果，これらの形質の多くに系統間で有意な差違が認められた。また開花まで日数掞よび成熟までの諸形 質と 100 粒重以外の収量構成要因相互間に有意な正の相関があった。100 粒重と他の生育・収量構成要因との間には負 の相関があり，生育と子実の充実の間にトレードオフがあることを示唆した。また，種子形状比（厚み/幅）と栽培 高度との間に有意な正の相関が認められ, 栽培高度が形質多様性創出の一因と成り得ることが示唆された. 調べた生育・ 収量構成要因と種子形態について主成分分析を行い, 形質の類似性と地理的分布との関係を調べたが, 愛媛県広田村 (旧 名）の系統を除いて，明らかな関係は認められなかった，系統間の遺伝的距離と地理的距離の間には正の相関が見ら れる一方で, 遺伝的距離の近い系統間にも大きな形質の差違が認められた.
\end{abstract} キーワード：四国山地，種子形態，生育・収量，ダイズ，地方品種，焼畑.

四国山地は 1960 年代まで規模と密度において日本でも 有数の焼畑地帯であった（佐々木 1972）。「50 年センサス」 の時点で，四国山地には全国の焼畑の約 19\%余にあたる 2271.3 町歩の焼畑が分布していた（農林省統計調査部 1955)。ここでは多くの作物と雑穀類が作られてきており， 相馬（1962）は焼畑の時期, 作物の作付け順序と種類によっ て焼畑にいくつかの地域的区分があることを明らかにし た。焼畑作物の中でもダイズ (Glycine max (L.) Merr.) は 日本人の食生活に定着して, 最も古くから, また一般的に 用いられてきたものである。四国山地に遺存するダイズ地 方品種は様々な地域環境に適応して育成され，さらに山村 住民の用途や嗜好および多収量性などの要求によって人為 的な選抜が加味されたものと想像される. Huan ら (2005) は四国山地山村から収集したダイズ地方品種系統について RAPD 法を用いた解析を行い, これらがきわめて遺伝的変 異に富んだものであることを明らかにした。これらのダイ ズ地方品種系統には Li and Nelson（2001）によって示され た日本の全国各地から収集されたダイズ地方品種系統に見 られる遺伝的変異の約 $80 \%$ が維持されていた。このよう な遺伝的変異の多様性は表現型の多様性に反映されると考 えられる。このようなダイズ地方品種系統は山村文化の遺 産であり, 将来的な育種素材, あるいは遺伝資源として保 存することが望まれる.

本研究では焼畑耕作の卓越地であった四国山地西部山村 から収集したダイズ地方品種系統について，これらを遺伝 子資源として評価するために, 系統間でどれくらいの表現 型変異があるのかを生育と収量に関係する諸形質および種
子形態について調べた。ささら Huanら（2005）によって 得られた系統間の遺伝的な近縁関係と表現形質との関係, および変異の地理的分布についていくつかの統計的手法を 用いて検討した.

\section{材料と方法}

\section{1.ダイズ地方品種系統の収集}

2000 年に愛媛県および高知県にまたがる四国山地西部の 山村農家を訪問し, ダイズ種子を収集した。37の農家か ら合計 54 のダイズ地方品種系統を収集した。ここでは四 国山村で栽培されるダイズを総称して地方品種とよび, 各 農家で維持されているものをその系統とした。種皮色から これらの系統は黄色種皮 25 系統, 黒色種皮 17 系統, 褐色 種皮 2 系統, 緑色種皮 10 系統に分類された。採集地を第 1 表に示した。採集地の地名は種子の局在を示すために旧 名で記した。これらの種子は持ち帰って冷蔵庫 $\left(4^{\circ} \mathrm{C}\right)$ に 保管した。

\section{2. 生育・収量に関係する諸形質および種子形態の測定}

2001 年 6 月 2 日に系統当たり 25 粒の種子をバーミキュ ライトを入れた生分解性ポット（Jiffypot 丸型 $5.5 \mathrm{~cm}$ ) に 1 粒ずつ播種し, 愛媛大学農学部構内温室で発芽生育させ た. 6 月 25 日に健全な個体を系統あたり 8 個体選び，同 所戋場に畧間 $80 \mathrm{~cm}$, 株間 $18 \mathrm{~cm}$ で移植した。試験区画の 面積は $100 \mathrm{~m}^{2}$ で無反復とし, 基肥に窒素, リン酸, カリ を成分量でそれぞれ $3,10,10 \mathrm{~g} / \mathrm{m}^{2}$ 施用した。植栽の順 序は完全無作為化しておこなった。

\footnotetext{
2006 年 6 月 16 日 受理．連絡責任者：原田光 $\overline{7} 790-8566$ 愛媛県松山市樽味 3-5-7 
第 1 表 ダイズ地方品種系統の採集地.

\begin{tabular}{|c|c|c|c|c|c|}
\hline 地名 & 所在地 & 緯度 & 経度 & 高度（m） & 系統 \\
\hline 面河村西谷 & 愛媛県 & $33^{\circ} 41^{\prime} 13.4^{\prime \prime}$ & $133^{\circ} 04^{\prime} 29.8^{\prime \prime}$ & 696 & ${\mathrm{~B} 11^{*}}^{*}$ \\
\hline 面河村中村 & 愛媛県 & $33^{\circ} 40^{\prime} 20.8^{\prime \prime}$ & $133^{\circ} 04^{\prime} 06.4^{\prime \prime}$ & 592 & B10, G1 \\
\hline 面河村関門 & 愛媛県 & $33^{\circ} 42^{\prime} 25.5^{\prime \prime}$ & $133^{\circ} 05^{\prime} 39.8^{\prime \prime}$ & 666 & B9, G2 \\
\hline 面河村梅ヶ市 & 愛媛県 & $33^{\circ} 44^{\prime} 18.6^{\prime \prime}$ & $133^{\circ} 02^{\prime} 26.3^{\prime \prime}$ & 762 & B12 \\
\hline 面河村小網 & 愛媛県 & $33^{\circ} 44^{\prime} 34.1^{\prime \prime}$ & $133^{\circ} 00^{\prime} 14.8^{\prime \prime}$ & 893 & Y19, B8, G3 \\
\hline 美川村沢渡 & 愛媛県 & $33^{\circ} 36^{\prime} 27.8^{\prime \prime}$ & $132^{\circ} 59^{\prime} 36.5^{\prime \prime}$ & 632 & $\mathrm{Y} 23, \mathrm{~B} 15^{*}$ \\
\hline 美川村長崎 & 愛媛県 & $33^{\circ} 36^{\prime} 09.0^{\prime \prime}$ & $133^{\circ} 02^{\prime} 15.2^{\prime \prime}$ & 772 & $\mathrm{Y} 20$ \\
\hline 美川村黒藤川 & 愛媛県 & $33^{\circ} 34^{\prime} 27.5^{\prime \prime}$ & $133^{\circ} 00^{\prime} 33.1^{\prime \prime}$ & 404 & B18 \\
\hline 美川村大橡 & 愛媛県 & $33^{\circ} 35^{\prime} 13.0^{\prime \prime}$ & $132^{\circ} 55^{\prime} 02.8^{\prime \prime}$ & 988 & $\mathrm{~B} 13$ \\
\hline 美川村大川 & 愛媛県 & $33^{\circ} 36^{\prime} 28.9^{\prime \prime}$ & $132^{\circ} 56^{\prime} 07.9^{\prime \prime}$ & 472 & B14 \\
\hline 柳谷村西本 & 愛媛県 & $33^{\circ} 33^{\prime} 02.7^{\prime \prime}$ & $133^{\circ} 02^{\prime} 15.2^{\prime \prime}$ & 676 & $\mathrm{Y} 21$ \\
\hline 柳谷村西谷 & 愛媛県 & $33^{\circ} 31^{\prime} 15.9^{\prime \prime}$ & $132^{\circ} 57^{\prime} 37.3 "$ & 781 & Y24 \\
\hline 久万町中条 & 愛媛県 & $33^{\circ} 38^{\prime} 21.3^{\prime \prime}$ & $132^{\circ} 51^{\prime} 12.6^{\prime \prime}$ & 558 & $\mathrm{Y} 22, \mathrm{G} 4$ \\
\hline 久万町中組 & 愛媛県 & $33^{\circ} 41^{\prime} 51.6^{\prime \prime}$ & $132^{\circ} 57^{\prime} 52.6^{\prime \prime}$ & 536 & $\mathrm{~B} 16, \mathrm{~B} 17, \mathrm{G} 5$ \\
\hline 別子山村瓜生野 & 愛媛県 & $33^{\circ} 51^{\prime} 29.8^{\prime \prime}$ & $132^{\circ} 25^{\prime} 26.9^{\prime \prime}$ & 822 & Y25 \\
\hline 広田村篠谷 & 愛媛県 & $33^{\circ} 39^{\prime} 44.1^{\prime \prime}$ & $132^{\circ} 48^{\prime} 40.3^{\prime \prime}$ & 546 & $\mathrm{Y} 6$ \\
\hline 広田村中野川 & 愛媛県 & $33^{\circ} 38^{\prime} 55.7^{\prime \prime}$ & $132^{\circ} 46^{\prime} 44.5$ " & 533 & $\mathrm{Y} 4$ \\
\hline 広田村高市 & 愛媛県 & $33^{\circ} 37^{\prime} 28.9^{\prime \prime}$ & $132^{\circ} 46^{\prime} 14.7^{\prime \prime}$ & 534 & Y5 \\
\hline 小田町立石 & 愛媛県 & $33^{\circ} 33^{\prime} 33.5^{\prime \prime}$ & $132^{\circ} 45,50.1 "$ & 229 & $\mathrm{Y} 11, \mathrm{~B} 1, \mathrm{~B} 2, \mathrm{G} 6$ \\
\hline 小田町藤井 & 愛媛県 & $33^{\circ} 34^{\prime} 16.3^{\prime \prime}$ & $132^{\circ} 50^{\prime} 20.3 ”$ & 310 & Y12, B3 \\
\hline 川辺村北平 & 愛媛県 & $33^{\circ} 30^{\prime} 48.3^{\prime \prime}$ & $132^{\circ} 48^{\prime} 04.6^{\prime \prime}$ & 451 & Y9 \\
\hline 小田町植松 & 愛媛県 & $33^{\circ} 28^{\prime} 52.7^{\prime \prime}$ & $132^{\circ} 44^{\prime} 21.0^{\prime \prime}$ & 380 & G7 \\
\hline 野村町惣川 & 愛媛県 & $33^{\circ} 28^{\prime} 11.4^{\prime \prime}$ & $132^{\circ} 47^{\prime} 41.5 "$ & 695 & Y1 \\
\hline 野村町稲谷 & 愛媛県 & $33^{\circ} 28^{\prime} 10.0^{\prime \prime}$ & $132^{\circ} 47^{\prime} 08.7^{\prime \prime}$ & 359 & Y3 \\
\hline 野村町大和 & 愛媛県 & $33^{\circ} 28^{\prime} 54.8^{\prime \prime}$ & $132^{\circ} 49^{\prime} 30.1^{\prime \prime}$ & 686 & Y10 \\
\hline 城川町嘉喜尾 & 愛媛県 & $33^{\circ} 23^{\prime} 32.1^{\prime \prime}$ & $132^{\circ} 44^{\prime} 35.9^{\prime \prime}$ & 205 & Y15 \\
\hline 城川町遊子谷 & 愛媛県 & $33^{\circ} 2539.6^{\prime \prime}$ & $132^{\circ} 45^{\prime} 37.9^{\prime \prime}$ & 351 & $\mathrm{Y} 7, \mathrm{~B} 7$ \\
\hline 仁淀村泉 & 高知県 & $33^{\circ} 29^{\prime} 43.7^{\prime \prime}$ & $133^{\circ} 06^{\prime} 11.0^{\prime \prime}$ & 572 & Y8, B5 \\
\hline 仁淀村松原 & 高知県 & $33^{\circ} 30^{\prime} 08.4^{\prime \prime}$ & $133^{\circ} 03^{\prime} 02.4^{\prime \prime}$ & 754 & G8 \\
\hline 東津野村口目ヶ市 & 高知県 & $33^{\circ} 27^{\prime} 06.6^{\prime \prime}$ & $133^{\circ} 01^{\prime} 51.2^{\prime \prime}$ & 701 & $\mathrm{Y} 14, \mathrm{~B} 4$ \\
\hline 檮原町大田戸 & 高知県 & $33^{\circ} 26^{\prime} 27.9^{\prime \prime}$ & $132^{\circ} 58^{\prime} 42.4^{\prime \prime}$ & 679 & Y16, G9 \\
\hline 檮原町井の谷 & 高知県 & $33^{\circ} 26^{\prime} 56.0^{\prime \prime}$ & $132^{\circ} 57^{\prime} 24.0^{\prime \prime}$ & 832 & $\mathrm{Y} 13$ \\
\hline 檮原町島中 & 高知県 & $33^{\circ} 18^{\prime} 16.3^{\prime \prime}$ & $132^{\circ} 58^{\prime} 46.3^{\prime \prime}$ & 362 & Y18 \\
\hline 檮原町東向 & 高知県 & $33^{\circ} 25 ' 28.8^{\prime \prime}$ & $132^{\circ} 53 ’ 20.7^{\prime \prime}$ & 669 & $\mathrm{~B} 19, \mathrm{G} 10$ \\
\hline 大正町下津井 & 高知県 & $33^{\circ} 17^{\prime} 22.1^{\prime \prime}$ & $132^{\circ} 56^{\prime} 00.6^{\prime \prime}$ & 330 & $\mathrm{Y} 2$ \\
\hline 大正町打井川 & 高知県 & $33^{\circ} 08^{\prime} 53.0^{\prime \prime}$ & $133^{\circ} 03^{\prime} 19.2^{\prime \prime}$ & 341 & $\mathrm{~B} 6$ \\
\hline 十和村野々川 & 高知県 & $33^{\circ} 11^{\prime} 01.8^{\prime \prime}$ & $132^{\circ} 54^{\prime} 22.1 "$ & 524 & $\mathrm{Y} 17$ \\
\hline
\end{tabular}

系統名のY，B，Gはそれぞれ黄色，黒色，緑色種皮系統を示寸。*で示した系統は褐色種皮系統.

成育に関する形質として, 開花まで日数 (FLT), 成熟 期の草丈 (PLH), 成熟期の子葉節から上の乾物重 (PLW), 一次分枝数 (BRN), 主茎節数 (NDS), 分枝節数 （NDB）を, また収量要因として植物個体当たりの萊総数 $(\mathrm{PDN})$, 個体当たりの結実種子総数 (SDN), 100 粒重 (SDW), 個体当たりの結実種子総重量（総種子重, YLD) を測定もしくはカウントした.さらに葉の光合成能力を比 較するために SPAD 值（SPD）を SPAD-502（ミノル夕） を用いて測定した，SPAD 值は栄養成長のほぼ完了した移 植 5 ないし 6 週間後に, 個体当たり 2 ないし 3 枚の葉の合 計 15 点を無作為にとって測定した.

収穫した種子については個体当たり 20 粒を無作為に選 び, 各種子の 3 次元計測值（長さ, 幅, 厚み) と重量を測 定した。種子形状比は Nelson and Wang（1989）に従って, 長さ/幅（HLR），厚み/幅（HTR）を算出した。

\section{3. データ解析}

生育と収量に関係する諸形質および種子形態の系統間差 異の統計解析は種皮色ごとにグループに分け, 以下のモデ ルにもとづいて枝分かれ分散分析（nested ANOVA）を行っ た.

$$
x_{\mathrm{ijk}}=\mu+\alpha_{\mathrm{i}}+\beta_{\mathrm{ij}}+\varepsilon_{\mathrm{ijk}} \cdot
$$

ここで, $x_{\mathrm{ijk}}$ は種皮色グループ $\mathrm{i}$ における, 系統 $\mathrm{j}$ の $\mathrm{k}$ 番目 の個体の測定值であり, $\mu$ は集団平均值， $\alpha_{\mathrm{i}}, \beta_{\mathrm{ij}}, \varepsilon_{\mathrm{ijk}}$ はそ れぞれ, 種皮色によるグループ分けの効果, 種皮色グルー プi 内の系統の効果, および $x_{\mathrm{ijk}}$ に付随するサンプリング エラー（環境要因）である。ささらに諸形質によって決定さ れる主要因を抽出し, 形態形質の類似性と地理的分布との 関係を調べるために主成分分析（PCA）を行った。また， 各系統間の遺伝的距離と形態形質類似度との相関は Mantel testによって検定した。系統間の遺伝的距離はHuan ら （2005）による RAPD デー夕を用いて算出した。 また系統 間の形質類似度は Goodman（1972）にもとづいて PCA の 主成分をもちいたマハラノビス標準化距離を算出した。 PCA および ANOVA は JMPv5 統計解析パッケージ（SAS International, USA) をもちいた。ここで種皮色によるグルー プ分けはHuan ら（2005）によって種皮色間に有意な遺伝 的分化が認められたことにより行った. 褐色種子は黒色種 
第 2 表 ダイズ地方品種系統の種皮色グループごとの生育・収量形質の平均值と変動係数.

\begin{tabular}{|c|c|c|c|c|c|c|c|c|c|c|c|}
\hline \multirow[t]{2}{*}{ 系統 } & \multicolumn{11}{|c|}{ 形質 } \\
\hline & $\begin{array}{l}\text { FLT } \\
\text { (day) }\end{array}$ & $\begin{array}{l}\text { PLH } \\
(\mathrm{cm})\end{array}$ & $\begin{array}{c}\text { PLW } \\
\text { (g) }\end{array}$ & BRN & NDS & NDB & PDN & SDN & $\begin{array}{c}\text { SDW } \\
(\mathrm{g})\end{array}$ & $\begin{array}{c}\text { YLD } \\
(\mathrm{g})\end{array}$ & SPD \\
\hline 黄色 & $\begin{array}{c}65.6 \\
(8.73)\end{array}$ & $\begin{array}{c}79.5 \\
(16.6)\end{array}$ & $\begin{array}{c}44.8 \\
(29.7)\end{array}$ & $\begin{array}{c}5.41 \\
(19.2)\end{array}$ & $\begin{array}{c}17.3 \\
(13.5)\end{array}$ & $\begin{array}{c}43.9 \\
(29.2)\end{array}$ & $\begin{array}{c}85.5 \\
(60.0)\end{array}$ & $\begin{array}{l}123.6 \\
(49.6)\end{array}$ & $\begin{array}{c}34.9 \\
(23.1)\end{array}$ & $\begin{array}{c}39.5 \\
(37.0)\end{array}$ & $\begin{array}{c}35.4 \\
(6.02)\end{array}$ \\
\hline 黒色 & $\begin{array}{c}61.8 \\
(5.13)\end{array}$ & $\begin{array}{c}81.6 \\
(12.4)\end{array}$ & $\begin{array}{c}47.5 \\
(20.7)\end{array}$ & $\begin{array}{c}4.80 \\
(15.6)\end{array}$ & $\begin{array}{c}18.1 \\
(10.5)\end{array}$ & $\begin{array}{c}38.9 \\
(18.3)\end{array}$ & $\begin{array}{c}65.8 \\
(53.8)\end{array}$ & $\begin{array}{c}93.0 \\
(43.3)\end{array}$ & $\begin{array}{c}46.7 \\
(25.9)\end{array}$ & $\begin{array}{c}40.0 \\
(23.7)\end{array}$ & $\begin{array}{c}34.0 \\
(5.15)\end{array}$ \\
\hline 緑色 & $\begin{array}{c}63.8 \\
(8.26)\end{array}$ & $\begin{array}{c}75.8 \\
(12.8)\end{array}$ & $\begin{array}{c}47.3 \\
(31.5)\end{array}$ & $\begin{array}{c}4.97 \\
(18.9)\end{array}$ & $\begin{array}{c}17.7 \\
(7.63)\end{array}$ & $\begin{array}{c}39.5 \\
(26.1)\end{array}$ & $\begin{array}{c}72.3 \\
(64.7)\end{array}$ & $\begin{array}{l}111.8 \\
(64.8)\end{array}$ & $\begin{array}{c}37.2 \\
(12.8)\end{array}$ & $\begin{array}{c}38.2 \\
(58.6)\end{array}$ & $\begin{array}{c}34.3 \\
(5.04)\end{array}$ \\
\hline
\end{tabular}

変動係数は各系統 8 個体の平均值についてもとめ, 平均值の下の（）内に\%で示した。形質の表記は以 下のように示す. FLT:開花まで日数, PLH : 草丈, PLW : 乾物重, BRN : 一次分枝数, NDS : 主茥節数, $\mathrm{NDB}$ : 分枝節数, $\mathrm{PDN}$ : 個体当たりの莢総数, SDN : 個体当たりの結実種子総数, SDW : 100 粒重, $\mathrm{YLD}$ : 個体当たりの総種子重, SPD : SPAD 值.

第3 表 ダイズ地方品種系統の生育・収量諸形質 について行った枝分かれ分散分析から求め た $\mathrm{F}$ 值および広義遺伝率.

\begin{tabular}{ccrc}
\hline & \multicolumn{2}{c}{ 変動要因 } & \\
\cline { 2 - 3 } 形質 & 種皮色 & \multicolumn{1}{c}{ 系統 } & 広義遺伝率 \\
\hline FLT & $3.36^{*}$ & $15.70^{* * *}$ & 0.65 \\
PLH & 0.85 & $10.70^{* * * *}$ & 0.56 \\
PLW & 0.25 & $3.41^{* * *}$ & 0.24 \\
BRN & 2.70 & $2.96^{* * *}$ & 0.21 \\
NDS & 0.73 & $12.69^{* * *}$ & 0.61 \\
NDB & 1.53 & $4.51^{* * *}$ & 0.32 \\
PDN & 1.10 & $6.20^{* * *}$ & 0.40 \\
SDN & 1.62 & $5.45^{* * *}$ & 0.37 \\
SDW & $9.47^{* * *}$ & $30.07^{* * *}$ & 0.79 \\
YLD & 0.02 & $3.02^{* * *}$ & 0.21 \\
SPD & $3.81^{*}$ & $1.60^{* *}$ & 0.11 \\
\hline
\end{tabular}

形質の表記は第 2 表に準ずる.

*および *** はそれぞれ，5\%，0.1\%水準で有意差有り。

子より $\mathrm{R}$ 遺伝子座の 1 ステップの突然変異によって生じる ことが知られており（Bernard and Weiss 1973），また得ら れた系統数が少ないことから, 黒色種子に含めて解析した. $\beta_{\mathrm{ij}}$ に由来する系統間の分散, $\sigma_{\mathrm{g}}^{2}$ (遺伝分散) と $\varepsilon_{\mathrm{ijk}}$ に由来 する環境分散, $\sigma_{\mathrm{e}}^{2}$ を上記 ANOVA から求め, 広義遺伝率, $\mathrm{H}^{2}$ の推定値を以下の式から求めた.

$$
\mathrm{H}^{2}=\sigma_{\mathrm{g}}^{2} /\left(\sigma_{\mathrm{g}}^{2}+\sigma_{\mathrm{e}}^{2}\right) \text {. }
$$

\section{結果}

生育および収量に関係する諸形質の平均値を種皮色グ ループごとに求め第 2 表にまとめた。種皮色グループ内の 系統間に大きな変異が見られたが, 中でも個体当たりの萊 総数 (PDN) および, 個体当たりの結実種子総数 (SDN) に変動係数の大きな值が示された。これらの諸形質につい て枝分かれ分散分析による $\mathrm{F}$ 検定の結果を第 3 表に示した. 種皮色によるグループ分けの効果は, 開花まで日数（FLT）,
100 粒重（SDW）および SPAD 值（SPD）で有意であった。 100 粒重（SDW）での効果は特に大きく, 黒色種皮のもの が最も重いことを示した。種皮色グループ内の系統間で $\mathrm{SPAD}$ 值（SPD）を除くすべての形質で大きな有意差が見 られた。これにより, 広義遺伝率は開花まで日数（FLT）, 草丈 (PLH), 主茎節数 (NDS), 100 粒重 (SDW) などで 0.5 を超える大きな值となった一方で，一次分枝数（BRN）, 個体当たりの総種子重 (YLD) および SPAD 值 (SPD) は 0.2 かそれ以下の比較的小さな值となった。栽培地の高度は形 質多様化の要因と考えられるため, これを含んだ諸形質相 互の相関係数を求め第 4 表に示した. 種子採集地高度(ALT) はほとんどの生育および収量に関係する形質と有意な相関 を示さなかった。しかしながら, 種子採集地高度 (ALT) と個体当たりの総種子重（YLD）との間には $5 \%$ レベルで はあるが，負の相関があり，また他の形質との相関は有意 ではないものの負の值を示すものが多いことは注目され る. 開花まで日数 (FLT) は乾物重 (PLW), 一次分枝数 (BRN) および SPAD 值 (SPD) 以外の生育・収量形質と有意な相 関があった. 100 粒重（SDW）以外は正の相関であった。 収量に関係する諸形質, すなわち, 個体当たりの萊総数 (PDN), 結実種子総数 (SDN) および個体当たりの総種子 重（YLD）は互に高い正の相関があるとともに，生育に関 係する形質の多くとも相関があった。 100 粒重（SDW）は 乾物重（PLW）抢よ゙個体当たりの総種子重（YLD）以外 の他の形質と負の相関傾向を示し, 特に開花まで日数 (FLT), 萊総数 (PDN) おょび結実種子総数 (SDN) との 相関の有意性は顕著であった。 SPAD 值（SPD）はすべて の形質と有意な相関を示さなかった.

種子の形態に関係する諸形質について種皮色グループご との平均値を第 5 表に示した。これらの諸形質について枝 分かれ分散分析による $\mathrm{F}$ 検定の結果を第 6 表に示した。種 皮色グループの違いは種子の厚みを除く 3 次元計測值およ び種子重量で顕著であった。黒色種子がサイズ, 重量とも 最も大きかった，形状比については種皮色グループ間で有 
第 4 表 ダイズ地方品種系統の採集地高度と生育・収量諸形質相互の相関係数.

\begin{tabular}{|c|c|c|c|c|c|c|c|c|c|c|c|}
\hline \multirow[t]{2}{*}{ 形質 } & \multicolumn{11}{|c|}{ 相関係数 } \\
\hline & FLT & PLH & PLW & BRN & NDS & NDB & PDN & SDN & SDW & YLD & SPD \\
\hline ALT & 0.031 & -0.102 & -0.209 & -0.124 & -0.184 & -0.153 & -0.274 & -0.223 & 0.010 & $-0.318^{*}$ & -0.016 \\
\hline FLT & & $0.522^{* * *}$ & 0.099 & 0.239 & $0.581^{* * *}$ & $0.607^{* * *}$ & $0.542^{* * * *}$ & $0.660^{* * * *}$ & $-0.644^{* * *}$ & $0.327^{*}$ & 0.032 \\
\hline PLH & & & $0.499^{* * *}$ & 0.120 & $0.827^{* * *}$ & $0.603^{* * *}$ & $0.625^{* * * *}$ & $0.668^{* * *}$ & -0.266 & $0.554^{* * *}$ & -0.071 \\
\hline PLW & & & & $0.491^{* * *}$ & $0.351^{*}$ & $0.612^{* * * *}$ & $0.448^{* * * *}$ & $0.510^{* * * *}$ & 0.213 & $0.719^{* * * *}$ & -0.079 \\
\hline BRN & & & & & 0.001 & $0.746^{* * *}$ & $0.405^{* *}$ & $0.450^{* * *}$ & -0.051 & $0.462^{* * *}$ & 0.030 \\
\hline NDS & & & & & & $0.554^{* * *}$ & $0.566^{* * *}$ & $0.626^{* * *}$ & $-0.344^{*}$ & $0.438^{* * *}$ & -0.143 \\
\hline NDB & & & & & & & $0.688^{* * *}$ & $0.777^{* * *}$ & $-0.333^{*}$ & $0.653^{* * *}$ & -0.034 \\
\hline PDN & & & & & & & & $0.940^{* * *}$ & $-0.435^{* *}$ & $0.666^{* * *}$ & 0.026 \\
\hline SDN & & & & & & & & & $-0.516^{* * *}$ & $0.775^{* * *}$ & 0.012 \\
\hline SDW & & & & & & & & & & 0.002 & -0.129 \\
\hline YLD & & & & & & & & & & & -0.048 \\
\hline
\end{tabular}

ALT: 種子採集地高度. 他の形質の表記は第 2 表に準ずる.

*，**および***はそれぞれ，5\%，1\%，0.1\%水準で有意差有り.

第 5 表 ダイズ地方品種系統の種子形態の種皮色 グループごとの平均值と変動係数.

\begin{tabular}{ccccccc}
\hline 系統 & $\begin{array}{c}\text { 幅 } \\
(\mathrm{mm})\end{array}$ & $\begin{array}{c}\text { 長さ } \\
(\mathrm{mm})\end{array}$ & $\begin{array}{c}\text { 厚み } \\
(\mathrm{mm})\end{array}$ & $\begin{array}{c}\text { 種子重 } \\
(\mathrm{g})\end{array}$ & HLR & HTR \\
\hline 黄色 & 8.18 & 9.30 & 7.05 & 0.36 & 1.14 & 0.86 \\
& $(8.56)$ & $(10.4)$ & $(9.36)$ & $(26.1)$ & $(3.77)$ & $(5.93)$ \\
黑色 & 9.17 & 10.43 & 7.68 & 0.47 & 1.14 & 0.84 \\
& $(10.9)$ & $(11.0)$ & $(14.6)$ & $(29.1)$ & $(3.42)$ & $(6.67)$ \\
緑色 & 8.67 & 9.69 & 7.14 & 0.39 & 1.12 & 0.82 \\
& $(6.23)$ & $(8.67)$ & $(5.74)$ & $(16.9)$ & $(4.55)$ & $(3.05)$ \\
\hline
\end{tabular}

変動係数は 20 粒の平均值について各系統 8 個体の平均值 から求め, 平均值の下の ( )内に\%で示した.

HLR: 長さ/幅

HTR: 厚み/幅

第 7 表 主成分分析から求めた最初の 4 つの主成分の 固有值および固有ベクトル

\begin{tabular}{crrrr}
\hline & \multicolumn{4}{c}{ 固有ベクトル } \\
\cline { 2 - 5 } 形質 & PC1 & PC2 & PC3 & PC4 \\
\hline FLT & 0.32 & -0.40 & 0.05 & -0.22 \\
PLH & 0.35 & -0.08 & -0.25 & -0.11 \\
PLW & 0.33 & 0.40 & -0.11 & 0.17 \\
BRN & 0.30 & 0.24 & 0.28 & 0.13 \\
NDB & 0.44 & 0.03 & 0.08 & -0.01 \\
SDN & 0.44 & -0.16 & -0.04 & 0.06 \\
SDW & -0.17 & 0.57 & -0.15 & 0.24 \\
YLD & 0.38 & 0.18 & -0.13 & 0.25 \\
SPD & -0.01 & -0.09 & 0.72 & 0.12 \\
HLR & 0.08 & 0.38 & 0.50 & -0.40 \\
HTR & -0.03 & -0.27 & 0.19 & 0.77 \\
\hline 固有值 & 4.39 & 1.90 & 1.31 & 1.15 \\
寄与率 (\%) & 39.9 & 17.3 & 11.9 & 10.4 \\
累積寄与率 (\%) & 39.9 & 57.2 & 69.1 & 79.5 \\
\hline
\end{tabular}

形質の表記は第 2 表および第 5 表に準ずる.
第 6 表 ダイズ地方品種系統の種子形態諸形質に ついて行った枝分かれ分散分析から求めた $\mathrm{F}$ 值および広義遺伝率.

\begin{tabular}{cccc}
\hline & \multicolumn{2}{c}{ 変動要因 } & \\
\cline { 2 - 3 } 形質 $^{1)}$ & 種皮色 & 系統 & 広義遺伝率 \\
\hline 幅 & $8.57^{* * *}$ & $43.62^{* * *}$ & 0.69 \\
長さ & $6.88^{* *}$ & $29.83^{* * *}$ & 0.60 \\
厚み & $3.24^{* *}$ & $49.22^{* * *}$ & 0.71 \\
種子重 & $6.70^{* *}$ & $43.43^{* * *}$ & 0.68 \\
HLR & 0.92 & $6.29^{* * *}$ & 0.21 \\
HTR & 2.94 & $23.8^{* * *}$ & 0.54 \\
\hline
\end{tabular}

形質の表記は第 5 表に準ずる.

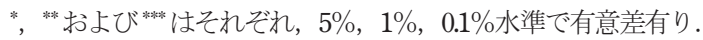

意な差はなかった。すべての項目について種皮色グループ 内の系統間にはきわめて大きな有意差が見られた。

生育・収量形質と, 種子形状比について形態的な類似に よるグループの判別と, その地理的な分布との関係を調べ るために主成分分析 (PCA) を行い, その結果を第 7 表に 示した．ここで主茎節数（NDS） と個体当たりの萊総数 （PDN）はそれぞれ，草丈（PLH）と個体当たりの結実種 子総数 $(\mathrm{SDN})$ との間に高い相関を示したため除外した. 第 1 主成分から第 4 主成分までの固有值が 1 以上の值を示 し，これらによる累積寄与率は $79.5 \%$ となった。第 1 主 成分を $\mathrm{X}$ 軸，第 2 主成分を $\mathrm{Y}$ 軸に取った座標平面上の各 系統の分布を第 1 図に示した。黄色揖よび緑色の種皮色グ ループ系統はほぼ同一の分布範囲を示したが，黒色種皮グ ループは第 1 主成分についてより幅が狭く，第 2 主成分に ついて正方向に偏った分布を示した，町または村単位で採 集した種子系統について種皮色グループごとに主成分座標 平面上でまとまったグループを作るかどうかを調べたが, 愛媛県広田村で採集された黄色 3 系統（Y4，Y5，Y6）を 除いて明確な形態の類似性を示すものはなかった。遺伝的 


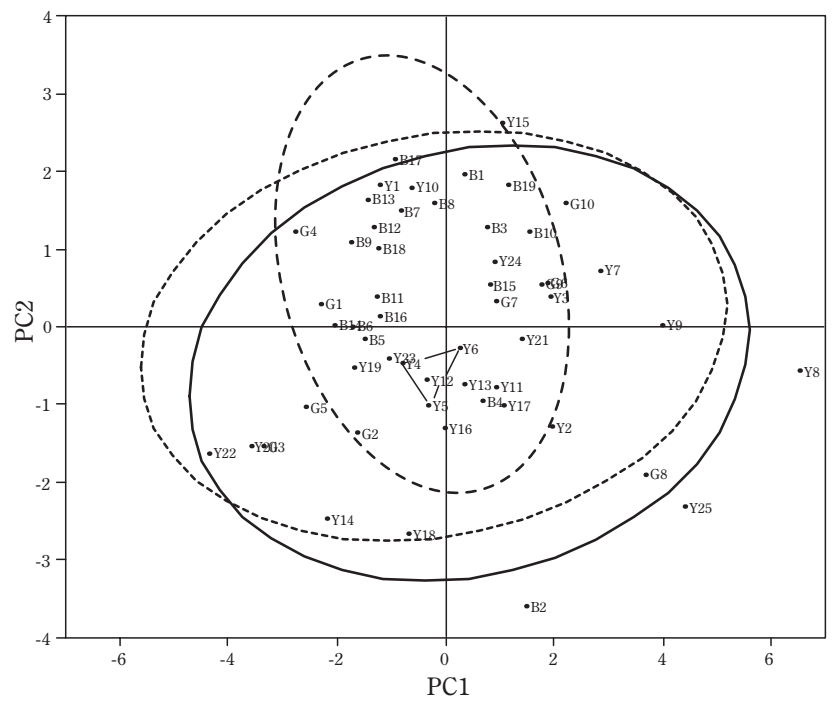

第 1 図 第 1 主成分（PC1）および第 2 主成分（PC2）について ダイズ地域品種54系統の散布図.

単線，破線および点線による円周は、それぞれ黄色，黒色 および緑色種皮系統の $90 \%$ 密度棈円。愛媛県広田村で採集 された3系統を直線でつないだ。

距離と形態的類似性との関係を調べるために, 第 4 主成分 までの值をもちいた系統間のマハラノビス距離と遺伝的距 離間の関係を第 2 図に示し，その相関の有意性を Mantel testによって検定した。 その結果, $P=0.041$ となり, 両 者の間に正の相関が認められた。また系統間の形態的距離 の平均值は $3.87 \pm 1.58(\mathrm{SD})$, 形態的距離の遺伝的距離 上の回帰式は $\mathrm{Y}=6.18 \mathrm{X}+3.17$ となった。第 2 図では, 形態的距離は遺伝的距離に関して大きくばらついており, 遺伝的距離の近い系統間にも大きな形質の差違があること が示された。

\section{考察}

四国山地西部の山村から収集したダイズ地方品種には生 育と収量に関係する形質の多くで系統間に大きな差違が認 められた。 これらの形質の中で開花まで日数はダイズ品種 の分類に広く用いられている. 福井・荒井（1951）は開花 まで日数が日本列島北部で南部に比べ短くなる傾向を見出 しており，これによって日本のダイズの地方品種をI， II,

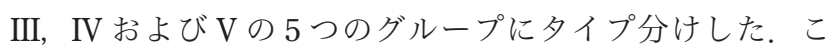
れらのグループは成熟まで日数によってさらに細かく分け られ，これによって四国の地方品種は IVcもしくはVcグ ループに区分されている (福井・荒井 1951). 本研究では, 開花まで日数（FLT）と個体当たりの萊総数（PDN）や結 実種子総数（SDN）の間に正の相関があり, 一方でこれら と 100 粒重（SDW）の間に強い負の相関があることを示し た (第 4 表)。このことは，開花までの期間が長い晚生系 統では栄養成長期間が長く, 多くの萊をつけ子実数も多い が，粒重との間でトレードオフが生じ，100 粒重が軽くな ることを示していると考えられる。多くの一年草や多年草

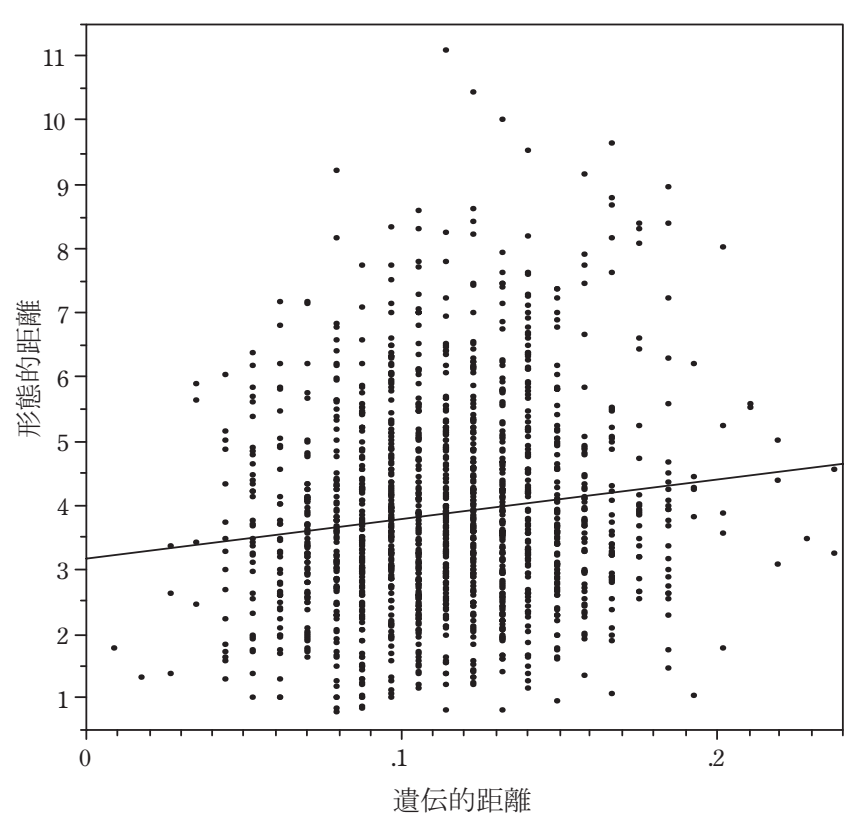

第 2 図 遺伝的距離と形態的距離との相関.

横軸に系統間の遺伝的距離, 縦軸にマハラノビス標準化距 離による形態的距離を示した。回帰直線はY=6.18X+3.17.

植物でこのような限られた資源のもとでのトレードオフが あることが知られている (Silvertown and Charlesworth 2001).

$\mathrm{SPAD}$ 值（SPD）は $650 \mathrm{~nm}$ および $940 \mathrm{~nm}$ における透過吸 光度の比をとって単位面積当たりの葉緑体量あるいは窒素 量を示すものとされるが (Markwell ら 1995), 我々のデー 夕は SPAD 值（SPD）の系統間の差異は, 他の形質と比較 してかなり小さいことを示した。生育や収量に関係する形 質の系統間の大きな差違は, 葉の葉緑体密度の違いよりも むしろ，葉面積や炭酸同化の際の転流効率に依存するもの と考えられる。

系統間の大きな差違は種子のサイズや形態 (形状比) に ついても見られた (第 6 表)。多くの形質で遺伝率は 0.5 以上の大きな值を示した。種子サイズについては種皮色グ ループの間で有意な差が見られたが，種子形態については 有意差はなかった，種子サイズは種子重と強い正の相関を 示したが，種子形態とは相関がなかった（デー夕省略）。 同様な結果, すなわち, ダイズ種子サイズと種子形態の遺 伝率が大きいこと，またその間に有意な相関がないことが Cober ら（1997）により親子回帰を用いて示されている. 種子サイズと形態に関係する諸形質と採集地高度 (ALT) との相関を調べたが, 形状比 HTR（厚み/幅）との間にの み負で有意な相関 $(r=-0.384, P<0.01)$ が見られた. このことは高度が高くなるにつれて種子 (子葉) の形状は 扁平になることを示しており, 高い高度での気温の低下, 水分条件および日照条件の変化に対する適応的な選択の結 果と考元られる。

主成分分析を用いて形質の類似性にもとづくグループの 判別，抒よびその地理的局在性について調べた（第 7 表お 
よび第 1 図)。第 1 主成分は開花まで日数（FLT）と成熟 期の草丈 (PLH), 乾物重 (PLW), 一次分枝数 (BRN), 分枝節数 (NDB), 100 粒重 $(\mathrm{SDN})$ なぞ栄養成長に関連 する形質，および個体当たりの総種子重（YLD）の寄与が 大きく，植物体の大きさを決定していると考えられる．第 2 主成分には 100 粒重（SDW）および乾物重（PLW）が正 で大きく寄与し，一方で開花まで日数（FLT）が負に大き く寄与している。これらは植物体や子実の充実を決定づけ る要因と考元られる。第 3 主成分ではSPAD 值（SPD）の 寄与が最も大きく, 葉の単位面積あたりの葉緑体量に依存 する．第 4 主成分では種子形態の二つの形状比（HLR, HTR）の寄与が最も大きく, 種子形状による区分を示して いるが，両者の符号は逆であるので細長く平たいものと， 短く太い形状のものが区別されることになる。第 1 および 第 2 主成分による座標平面（第 1 図）では黒色種皮系統は 黄色，もしくは緑色系統に対して第 1 主成分の変動幅が少 なく，第 2 主成分は正方向に偏っていた。これは，黒色種 皮系統の植物体サイズの変動が小さく, 種子重がより重い 方へ偏っていることを示している（第 2 表）。また，黒色 種皮系統は第 3 主成分についても変異の幅が少なく, 一方, 緑色種皮系統は第 4 主成分について変異の幅が狭かった. これらのことは種皮の色によって成長の度合いや種子の充 実，および種子形態が区分されることを示しており，Huan ら（2005）によって示された種皮色グループの遺伝的区分 とも一致する傾向を示した。種子採集地と形態的類似性と の関係を町や村ごとに調べたが広田村で採集した黄色種子 3 系統（Y4，Y5，Y6）以外は明確な形態的類似性は示され なかった. Huan ら (2005) の RAPD デー夕を用いて系統間 の遺伝的距離を求めると, $\mathrm{Y} 4-\mathrm{Y} 5$ 間で $0.036, \mathrm{Y} 4-\mathrm{Y} 6$ 間で 0.091, Y5 - Y6 間で 0.091 となり，いずれも黄色種 子全体での平均值 $0.114 \pm 0.0273$ よりかなり小さく, こ れらの系統は遺伝的にも近縁であることが示された。この ことは広田村の 3 系統が, ある程度の遺伝的変異を含む初 源系統に由来した可能性を示している. 形態的類似性と地 理的分布の間に一般的関係が見られなかったことは長い栽 培期間の間に種子が人の移動に伴って広範囲に拡散したこ と, おょび地域特有の環境または人為による選択を受けた ことが理由として考えられる。

本研究では四国山地のダイズ地方品種間に生育・収量形 質や種子形態に関して多様な変異があることが示された が, Huan ら（2005）は RAPD 解析にもとづいて，これら の品種遺伝子プールに外部遺伝子ソースからの繰返し導入
があったこと，また長い栽培の歴史の中で系統間の交雑も 生じたことを示唆している。これらのことは遺伝子プール の遺伝的変異を増加させ, これを素材として多様な環境下 での自然選択と, 栽培者の人為的な選択により表現型の多 様性が生み出されたと考えられる。なかでも栽培地の高度 の違いは, 気温や水分, 日照条件の違いのほか, 共生根粒 菌の種類や病害虫の関与など生態系の違いを通して表現型 の違いを生み出す主要な要因になったと想像される。本研 究では限られた形質のみが高度との相関を示したが，本研 究では示さなかった成熟までの日数, 葉面積, 種子の栄養 成分, 病害虫抵抗性などについての調査が栽培高度を含め た多様性生成機構を明らかにしていくために今後の必要な 研究課題として残された。

\section{引用文献}

Bernard, R. L. and M. G. Weiss 1973. Qualitative genetics. In Caldwell, B. E. ed. Soybeans: Improvement, Production, and Uses. Agron. Monor. 16, ASA, Madison, Wisconsin. 117-154.

Cober E. R., H. D. Voldeng and J. A. Fregeau-Reid 1997. Heritability of seed shape and seed size in soybean. Crop Sci. 37 : 1767-1769.

福井重郎・荒井正夫 1951. 日本に於ける大豆品種の生態学的研究. 1 . 開花日数と結実日数による品種の分類とその地理的分布に就い て. 育種学雑誌 27-39.

Goodman, M. M. 1972. Distance analysis in biology. Sys. Zool. 21 : 174186.

Huan, N. V., H. Sugimoto and K. Harada 2005. Genetic variation of local varieties of soybean in the western part of the Shikoku Mountains in Japan. Breed. Sci. 55 : $441-446$.

Li, Z. and R. L. Nelson 2001. Genetic diversity among soybean accessions from three countries measured by RAPDs. Crop Sci. 41 : $1137-1147$.

Markwell, J., J. C. Osterman and J. L. Mitchell 1995. Calibration of the Minolta SPAD-502 leaf chlorophyll meter. Photosyn. Res. 46 : 467472.

Nelson, R. L. and P. Wang 1989. Variation and evaluation of seed shape in soybean. Crop Sci. 29 : 147-150.

農林省統計調查部 1955. 1950 年世界農業センサス市町村別統計表. 農林水産省。

佐々木高明 1972. 日本の焼畑. 古今書院, 東京. 1-457.

Silvertown, J. W. and D. Charlesworth 2001. Intorduction to Plant Population Biology. 4th ed. Blackwell Science, London. 1-347.

相馬正胤 1962. 四国山岳地方における焼畑経営の地域構造. 愛媛大 学紀要 (社会科学) $4: 1-79$. 
Quantitative Variation in Growth and Yield-Related Traits and Seed Morphology in Local Varieties of Soybean in the Western Part of the Shikoku Mountains : Ko Harada ${ }^{1)}$, Nguyen Van Huan ${ }^{2)}$ and Hideki Sugimoto ${ }^{1)}\left({ }^{1)}\right.$ Fac. of Agr., Ehime Univ., Matsuyama, Ehime 790-8566, Japan; ${ }^{2)}$ United Grad. Sch. of Agr. Sci., Ehime Univ.)

Abstract : Fifty-four accessions of local soybean strains were collected from villages in the western part of the Shikoku Mountains and examined for morphological traits associated with growth, yield, seed size and seed shape. They included 25 yellow, 17 black, 2 brown and 10 green seed-coat color strains. Nested analysis of variance revealed large morphological variation among strains within the seed-coat color groups but hardly any significant difference among the color groups except seed weight. Significant positive correlations were found among growth and reproduction related characters except seed weight. Seed weight was negatively correlated with those characters, indicating a trade-off corresponding to the resource allocation to growth and maturation of seeds. There was a significant negative correlation between altitude of collection sites and seed shape (height/thickness), suggesting that altitude can be a factor causing diversification of seed morphology. Principal component analysis (PCA) was carried out on eleven morphological traits. No clustering in regional populations was shown on the plane determined by the first two principal components except in Hirota Village (old name), in Ehime Prefecture. There was a positive correlation between genotypic distance revealed by random amplified polymorphic DNA (RAPD) analysis and phenotypic distance. However, a large phenotypic variation was observed even between genetically very closely related strains.

Key words : Growth and yield, Local varieties, Seed morphology, Shifting cultivation, Shikoku Mountains, Soybean. 